\title{
The Correlation between the Covid-19 Pandemic and Domestic Abuse Against Women: A Comparative Study Between Australia, Indonesia, and India
}

\author{
Jessica Ruth Andina ${ }^{1}$, Marvel Tanara ${ }^{2}$, Dzaky Putra Wirahman ${ }^{3}$ \\ ${ }^{1}$ Faculty of Political Sciences, Universitas Katolik Parahyangan, jeruthandina@ gmail.com, ${ }^{2}$ Faculty of Political \\ Sciences, Universitas Katolik Parahyangan, marveltanara@gmail.com, ${ }^{3}$ Faculty of Political Sciences, \\ Universitas Katolik Parahyangan dzakywirahman@gmail.com
}

\begin{abstract}
The onset of the Covid-19 global pandemic in early 2020 forced many governments to quarantine their citizens within their own homes over the course of the year - namely from the early to middle months of the year. This was then followed by a surge of domestic violence cases against women, most often by their own spouses. This problem seemed to be a global problem as it affected any countries regardless of how high or low, they score in the Gender Development Index. This paper attempts to discuss the factors behind such a phenomenon and scrutinize what it represents through the lenses of gender theories. The paper will also analyses the studied countries' governments' approach to this issue. To that end, three countries from three different levels of GDI rankings are studied: Australia (ranked high), Indonesia (ranked medium) and India (ranked low). A brief explanation regarding this non-endemic issue will also be drawn from each countries' individual variables.
\end{abstract}

Keywords: domestic violence, women, patriarchy, toxic masculinity, gender equality

\begin{abstract}
ABSTRAK
Permulaan pandemi global Covid-19 pada awal tahun 2020 memaksa pemerintah untuk mengkarantina warganya di dalam rumah mereka sendiri sepanjang tahun - yaitu dari bulan-bulan awal hingga pertengahan tahun. Hal ini kemudian disusul dengan maraknya kasus KDRT terhadap perempuan yang paling sering dilakukan oleh pasangannya sendiri. Masalah ini tampaknya menjadi masalah global karena memengaruhi negara mana pun terlepas dari seberapa tinggi atau rendah peringkat mereka dalam Indeks Pembangunan Gender. Makalah ini mencoba membahas faktor-faktor di balik fenomena tersebut dan meneliti apa yang diwakilinya melalui lensa teori gender. Makalah ini juga akan menganalisis pendekatan pemerintah negara yang dipelajari untuk masalah ini. Untuk itu, tiga negara dari tiga tingkat peringkat Indeks Pembangunan Gender yang berbeda: Australia (peringkat tinggi), Indonesia (peringkat menengah) dan India (peringkat rendah). Penjelasan singkat mengenai masalah non-endemik ini juga akan diambil dari variabel individu masing-masing negara.
\end{abstract}

Kata Kunci: kekerasan dalam rumah tangga, perempuan, patriarki,toxic masculinity, kesetaraan gender

\section{Introduction}

Since December of 2019, the world has been taken by storm by the Novel Coronavirus Disease, or more commonly known now as Covid-19. The virus was first detected in Wuhan, Hubei Province, PR China. ${ }^{1}$ The condition set by the rapid spread of the disease continues to worsen in almost every country on earth. In just a span of days, the disease has spread throughout not just cities and countries, but entire continents. In March of 2020, the World Health Organization (WHO)

\footnotetext{
1 "Novel Coronavirus(2019-nCoV) Situation Report- 1", World Health Organization, January 21th 2020, https://www.who.int/docs/default-source/coronaviruse/situation-reports/20200121-sitrep-1-2019-ncov.pdf (accessed on September 21th, 2020)
} 
declared the virus to be a global pandemic - thus ensuring that the virus and its spread can no longer be taken lightly. ${ }^{2}$

There has been plenty of losses and limitations imposed upon many aspects of human life due to the pandemic, whether it is economic, mobility or mental health. With many country governments imposing a lockdown that entails a work from home policy. This policy however has been shown to decrease the productivity of workers due to various factors not experienced in a normal workplace. The world economy has also slipped into recession as many companies of various sectors are reporting record losses and deficits, thus forcing many who were part of their workforce to be laid off. This has resulted in the severance of income for many households globally - an effect that would surely have a long-term impact in the economic cycle of countries.

Another concern that has also been highlighted as a byproduct of this pandemic is the rise of domestic violence cases. Since the very beginning of the pandemic and throughout the time of the subsequent lockdowns, the numbers of domestic violence cases have increased. ${ }^{3}$ Before the pandemic, it was estimated that one in every three women experience some form of domestic violence at home. Things have only gotten worse as the lockdown measures have forced many women to be locked in at home with their abusers - enabling the latter to exert more of their violent urges upon the women. UN Women has issued a press release to try and bring awareness to society of the desperate predicaments many women find themselves in due to the pandemic. ${ }^{4}$ Interestingly, aside from economic factors, culture and social norms have also played a role in the worsening of this issue in various countries.

This important issue however is not so often discussed in public discussions as most discussions still focus on issues of economic recovery and monetary social aid. The issue of domestic violence itself at the moment is like the tip of an iceberg - an iceberg that has mostly been unseen in its full manifestation. This phenomenon also seems to be global as almost every single country has reported a rise in domestic violence cases. Due to that, this paper will discuss the question, "How much does the Covid-19 pandemic affect rates of domestic violence against women in Australia, Indonesia, and India?"

These three countries are chosen as they each represent a different ranking category of the Gender Development Index (GDI). Australia has a high GDI and is ranked in category 1, which means that the country has a high degree of gender equality between men and women (with an absolute deviation of less than 2.5\%). Indonesia has a medium GDI and is ranked in category 3, which means there are still medium disparities and inequalities between men and women (with an absolute deviation of 5-7.5\% $)^{5}$. India on the other hand has a low GDI and is ranked in category 5 with a very high disparity and inequality between men and women (with an absolute deviation from gender parity of

\footnotetext{
2 "WHO Director-General's opening remarks at the media briefing on COVID-19", World Health Organization, March 11th 2020, https://www.who.int/dg/speeches/detail/who-director-general-s-opening-remarks-at-the-media-briefing-on-covid-19--11-march-2020 (accessed on September

21th 2020)

3 "The COVID-19 Shadow Pandemic: Domestic Violence in the World of Work: A Call to Action for the Private Sector", $U N$ Women, 2020, https://www.unwomen.org/en/digital-library/publications/2020/06/brief-domestic-violence-in-the-world-ofwork (accessed on September 21th 2020)

4 "Press release: UN Women raises awareness of the shadow pandemic of violence against women during COVID-19", $U N$ Women, May 27th 2020, https://www.unwomen.org/en/news/stories/2020/5/press-release-the-shadow-pandemic-of-violence-against-womenduring-covid-19 (accessed on September 21th 2020)

5 "Gender Development Index," United Nation Development Programme Human Development Report, page 312-315, http://hdr.undp.org/en/content/table-4-gender-development-index (accessed on September 30th 2020).
} 
more than 10\%). Domestic violence is a global issue that has not been an often-focused issue in public discussion circles despite its widespread nature and the fact that the very act itself is a breach on human rights. The factors that lead to domestic violence are varied and are influenced by various external variables.

\section{Methodology}

The research method used in this research is a qualitative method. Quoting from Creswell, qualitative research is useful for exploring and understanding further about individuals and groups in a social phenomenon, which occurs at one time. ${ }^{6}$ The author will present ideas that have been previously stated by other authors/researchers and then reinterpret it. In this study, the authors will also further examine the phenomena that occur through data that have been presented by several reliable sources regarding the impact of domestic violence during the COVID 19 pandemic in Australia, Indonesia, and India. To confirm the reality and add information about this research, the authors have also conducted interviews with several non-governmental organizations that focus on dealing with domestic violence in their respective countries.

\section{Concept}

\section{Patriarchal Culture}

Patriarchies create patriarchal cultures, wherein despite social checks and balances being present, the conditions overwhelmingly benefit men. Men are more often in a privileged position of power, moral authority or various forms of favoritism in certain professions, vocations and social roles. ${ }^{7}$ Women and non-heteronormative people of all spectrum are usually relegated to less privileged positions in various aspects of life - whether it be filling less prestigious professional slots, being paid less than men or more commonly, being burdened with various archaic social expectations that are predisposed to disadvantage them one way or another. ${ }^{8}$ Patriarchal culture can manifest in not only social stigma and expectations to all genders, but also as a by-product of the normalization of said cultural values, become an institutional problem in more far-reaching entities such as governments and laws. Patriarchal cultures tend to favor heterosexual men and hold features and norms associated with 'masculinity' as being superior to things associated with femininity and non-heterosexual sexualities. This normalized form of microaggression aids in the internalization of patriarchal ideals by all members of said society - which then results in the prolongation and self-perpetuation of the patriarchal culture along with all its predisposed disadvantages exerted upon non-heterosexual men and women. ${ }^{9}$

\section{Domestic Violence}

Domestic violence is the act of using violence at home by the abuser to a family member who lives within their households. Based on data, two-thirds of all domestic violence victims are women. ${ }^{10}$

\footnotetext{
${ }^{6}$ John C. Creswell, Research Design: Qualitative, Quantitative, and Mixed Method Approaches (California: SAGE Publications, 2009).

${ }^{7}$ Carole Pateman, "Sexual Contract," The Wiley Blackwell Encyclopedia of Gender and Sexuality Studies (2016): pg. 1-3.

${ }^{8}$ Billy K. Sarwono, "Gender Bias in a Patriarchal Society," Wacana 14, no. 1 (April 2012): pg. 37-60.

${ }^{9}$ Carole Pateman, "Sexual Contract," The Wiley Blackwell Encyclopedia of Gender and Sexuality Studies (2016): pg. 1-3.

${ }^{10}$ Richard L.Davis, Domestic

Violence: Intervention, Prevention, Policies, and Solutions (Boca Raton: Taylor \& Francis Group, 2008):
} 
This phenomenon usually occurs due to three leading factors. The first one is the abuser's will to influence their victims by instilling values, beliefs or the abuser's intentions upon the victim. Secondly, as a knee-jerk emotional reaction usually justified as being caused by jealousy or grudges. And the third, is the abuser's intent to establish dominance within the household or even family. ${ }^{11}$ In the midst of continuously growing cases of domestic violence, many times the victims do not get the justice or resolution they deserve or demand due to the way this type of violence is almost normalized in various cultures. ${ }^{12}$

Based on Bonnie E. Carlson's study based on ecology, domestic violence can be examined through the levels of analysis of individuals, communities, social structure and sociocultural norms. From the individual level, domestic violence can be seen as being a byproduct of stress, childhood upbringing, environment or general interactions with other constituents of the household. From this aspect alone, one can relay the links between the factors and the conduct of domestic violence itself. From a community level, this is explained as being a byproduct of family environment, and it can be observed as being the result of community pressures and perhaps even social isolation of the household itself from the rest of the community. From these aspects, domestic violence will be discussed in this paper and suited with arguments from the corresponding units of analysis. ${ }^{13}$

\section{Gender Equality}

Gender equality is a condition where women and men enjoy the same obligation, rights, and opportunities in all aspects of life. ${ }^{14}$ This concept states that women and men are able to share their power and influence equally, they can experience the same level of education, they can pursue their ambition, passion, and talents without any intimidation and discrimination simply caused by their sex. The United Nations sees gender equality as a fundamental human right, but it is necessary for a more peaceful, prosperous, and sustainable world. This effort to achieve gender equality by the UN is caused by gender inequality that persists in some parts of the world, which hinder social progress. ${ }^{15}$ Gender inequality happens in a lot of aspects in everyday life, such as; economy, politics, education, and health. ${ }^{16}$ This disadvantage ranges from a very low chance of participation, opportunity, stereotype, and culture. Hence, lack of education that turns into very limited skill, that leads to limited job opportunities that women can get. Gender equality is very important to expand economic growth and promote social development in a country, creating a better condition for the wellbeing of its citizens.

\footnotetext{
pg. $8-10$.

${ }^{11}$ Ibid, pg. 17

12 Ibid, pg. 10-12.

${ }^{13}$ Lee E. Ross, Domestic Violence and Criminal Justice (New York: Routledge, 2018): pg. 46-49.

14 UNFPA, "Frequently asked questions about gender equality," United Nations Population Fund, 2005, https://www.unfpa.org/resources/frequently-asked-questions-about-gender-equality (accessed on September 24th 2020).

15“"Gender Equality: Why It Matters?" United Nations, https://www.un.org/sustainabledevelopment/wpcontent/uploads/2016/08/5_Why-It-Matters-2020.pdf (accessed on September 24th 2020).

${ }^{16}$ Kelly L. Hazel and Kerry S. Kleyman, “Gender and sex inequalities: Implications and resistance," Journal of Prevention and Intervention in the Community (2019).
} 


\section{Analysis}

\section{$\underline{\text { Australia }}$}

Australia is a developed country that has very good community growth. Australia ranks in 6th behind Norway, Switzerland, Ireland, Germany, and Hong Kong in the Human Development Index. ${ }^{17}$ However, in further review, Australia's Gender Development Index (GDI) is in position of 42, which is a fairly low ranking compared to other developed countries. ${ }^{18}$ This fact suggests that Australia is a country with excellent performance for men, but not for women. Men enjoy more favorable conditions of living, work and leadership in Australia than women. According to GDI which is based on the Gross National Income per capita, there is a \$16,459 gap between men's and women's earnings in Australia. ${ }^{19}$ The Australian Government needs to address this gender inequality, apart from being a human right, it is also an economic obstacle for Australia due to inability to get its full potential. This is because millions of women in Australia are belittled, and deemed unable to carry out work, therefore they are denied to fully participate in work and leadership. ${ }^{20}$

Australia's relatively low position in GDI compared to other developed countries is due to gender inequality that occurs in the daily lives of its citizens. One of the effects of gender inequality in society is domestic violence. This issue can happen among people in different regions, economic circles, and different ethnic groups, even though statistics shows that domestic violence is actually more frequent in the rural and indigenous communities of Australia. ${ }^{21}$ In 2019, cases of the reported domestic violence showed that two-thirds of the victims were women, with the majority offended by their intimate partner. ${ }^{22}$ In fact, according to data from the ABS Personal Safety Survey (PSS) in 2017, around one in six women (16 percent or 1,5 million) experienced abuse before the age of 15, just over one in ten men (11 percent or 991,600) in Australia. ${ }^{23}$

The outbreak of the COVID 19 pandemic around the world, including Australia, has had a negative impact on the conditions of domestic violence that occur in this country as well. According to a recent study in New South Wales and Queensland, the number of women reporting domestic violence did not increase from March to April 2020. However, some community services that address domestic violence and human behavior change, suggest that there is an increment of telephone services which has been made to request support since February $2020 .{ }^{24}$ In reality, little research has actually been carried out to detect domestic violence conditions since the start of the pandemic. This

\footnotetext{
17 "Human Development Index and its components," Human Development Report, 2019, http://hdr.undp.org/en/composite/HDI (accessed on September 28th 2020).

${ }_{18}$ Emma Dawson, Tanja Kovac, and Abigail Lewis, "Measure for Measure: Gender Equality in Australia," PerCapita (March 2020): pg 7.

${ }^{19}$ Ibid., pg 13.

${ }^{20}$ Ibid., pg 8.

21 Kerry Carrington, "Domestic Violence in Australia - an Overview of the Issues," Parliament of Australia, August $7^{\text {th }}$ 2003 ,

https://www.aph.gov.au/about_parliament/parliamentary_departments/parliamentary_library/publications_archive/archive/do mviolence (accessed on September 28th 2020).

22 "Recorded Crime - Victims, Australia," Australian Bureau of Statistics, July 9 $9^{\text {th }} 2019$, https://www.abs.gov.au/statistics/people/crime-and-justice/recorded-crime-victims-australia/latest-release\#victims-of-familyand-domestic-violence-related-offences (accessed on September $28^{\text {th }} 2020$ ).

23 "Personal Safety, Australia," Australian Bureau of Statistics, November $8{ }^{\text {th }} 2017$, https://www.abs.gov.au/statistics/people/crime-and-justice/personal-safety-australia/latest-release (accessed on September 29th 2020).

${ }^{24}$ Australian Government, "Statistical Bulletin” 28, Australian Institute of Criminology (July 2020): pg 2.
} 
happened because during the pandemic period, regulated quarantine obliges Australians to do more activities inside their homes.

Australian Institute of Criminology conducted a survey with 15,000 women respondents, aged 18 years and over from all over Australia. Respondents filled out a survey in May regarding their experiences with domestic violence since the start of the pandemic in February 2020. ${ }^{25} 8.8$ percent of women in a cohabiting relationship admitted to having experienced physical violence in the past three months, prior to the survey. ${ }^{26}$ This type of violence includes pushing and pulling, throwing items at them, slapping, being bitten, kicking, and beating. ${ }^{27} 2,2$ percent of all women and 4,2 percent of women in cohabiting relationships admitted to experiencing sexual violence during the first three months of the pandemic. Cohabiting partners are people who live, or have lived with the respondent for the last 12 months, or are married / have been married, or are in other de facto relationships. ${ }^{28}$ Also, 11,6 percent of all women and 22,4 percent of women in cohabiting relationships experienced emotionally abusive, harassing and controlling behaviors in their houses. This type of violence includes verbal abuse and insults, which are the most common forms of emotional violence, followed by suspicion and jealousy towards the respondent's friend. ${ }^{29}$

Among the women who experience physical or sexual violence before the pandemic, more than half ( 53 percent) of them admitted that violence perpetrated after the pandemic had become more frequent and severe, some reported it stayed the same (33,1 percent), and the minority reported the violence had decreased during the pandemic $(13,9 \%)$. Other than that, 47 percent of women who reported experienced coercive control said the abuse had frequently increased or became more severe, 39,3 percent admitted it stayed the same, and 13,7 said it had decreased. ${ }^{30}$

According to the survey conducted, it can be said that the COVID 19 pandemic has caused an increase in the frequency and severity of domestic violence that occurs in Australia. This can be due to several things; first, with quarantine policy in Australia starting on March 13, 2020, ${ }^{31}$ forcing all people in their homes to prevent the spread of the virus. This means that victims and perpetrators of violence spend more time together than before the pandemic. With this situation, it also hampers women as victims of domestic violence from seeking help because they will always be supervised by the perpetrator. This could explain why the number of domestic violence reported to the police has not significantly increased. ${ }^{32}$ In addition, domestic violence can also occur due to pressure caused by the effects of COVID 19, such as financial impacts and uncertainty of employment.

In responding to this issue, the Australian government has taken several steps. Under the government of Prime Minister Scott Morrison, the Australian government has provided \$ 150 million AUD to the frontline and national support services, as an emergency response to domestic violence that occurred due to the impact of COVID $19 .{ }^{33}$ In addition, in July 2020, the Morrison government

\footnotetext{
${ }^{25}$ Ibid.

${ }^{26}$ Ibid., pg 6.

${ }^{27}$ Ibid., pg 7.

${ }^{28}$ Ibid., pg 3.

${ }^{29}$ Ibid., pg 8.

${ }^{30}$ Ibid., pg 12.

${ }^{31}$ Calla Wahlquist, "Australia's coronavirus lockdown - the first 50 days," The Guardian, May $1^{\text {st }} 2020$, https://www.theguardian.com/world/2020/may/02/australias-coronavirus-lockdown-the-first-50-days (accessed on September 27th 2020).

${ }^{32}$ Australian Government, "Statistical Bulletin" 28, Australian Institute of Criminology, pg 16.

33 "Policy Brief: The Impact of COVID-19 on Women," United Nations, April 9 $9^{\text {th }} 2020$, pg 14.
} 
also provided assistance of $\$ 3$ million AUD to service providers who are expected to help with domestic violence counseling that occurs in all parts of Australia. ${ }^{34}$

From the explanation of the data above, it can be analyzed that domestic violence that occurs in Australia is rooted from gender inequality. All the "luxuries" enjoyed by men, such as higher salaries, higher opportunities, more representation in leadership, are just a few examples of the inequality that exists in the Australian public sphere. In the private sphere, domestic violence occurred. Before the pandemic, victims of domestic violence could seek protection from their families, community services, police and other related parties. However, after a pandemic, this will be very difficult to be implemented due to enforced quarantine policies, hampering the mobility and activities of victims.

The existence of a pandemic condition that makes unstable public financial conditions, is also a significant factor in the increment of domestic violence level in Australia. Violence committed by someone is used as an outlet for the uncertain condition that is currently happening. The fact that domestic violence still exists in almost all parts of Australia, proves that even countries with a very high Human Development Index can still experience domestic violence. This condition happened because of the patriarchal culture and gender inequality that still persist in Australia. With the poor gender equality that exists in Australia, put women in a disadvantage situation because women receive less opportunity than men in society.

In the author's research in Australia, the author has not been able to interview NGOs from Australia which handle domestic violence issues, but the authors hope that in the future they can conduct further research. Although, in the process of finding the NGOs to be interviewed, White Ribbon Australia, gave an email feedback to the author. White Ribbon is a movement that engages men and boys to end men's violence towards women and girls, promoting gender equality, and pushing society to create new opportunities for men to build a healthy relationship. They stated that the Coronavirus Supplement, a \$550 AUD Australian government's stimulus package, has benefited a lot of JobSeeker recipients. JobSeeker is a payment made by the government of Australia to citizens between the age of 22 and pension age that are unemployed or sick and injured, so they are unable to work or study for a short time. ${ }^{35}$ White Ribbon explained that crucial income support had provided "life changing, life-saving changes" to some women experiencing domestic violence throughout the pandemic. But, this financial boost is set to reduce by September $24^{\text {th }} 2020$ to $\$ 250$ per fortnight, taking some Australian families under the poverty line. This could enhance the chance of domestic violence happening, because of the financial problem that some Australian citizens face.

A statistics by the Australian Government on January 2019, shows the number of employed men are around 6,7 million, when employed women are only 5,9 million, proving that there are more men who work than women. ${ }^{36}$ Also, women receive 14 percent less earning than men in terms of full-

\footnotetext{
${ }^{34}$ Anthony Galloway, "Domestic violence on the rise during pandemic," The Sydney Morning Herald, July 13 ${ }^{\text {th }} 2020$, https://www.smh.com.au/politics/federal/domestic-violence-on-the-rise-during-pandemic-20200712-p55b8q.html (accessed on September 27th 2020).

35 "Who can get it," Australian Government Services Australia, https://www.servicesaustralia.gov.au/individuals/services/centrelink/jobseeker-payment/who-can-get-it (accessed on September 30th 2020).

36 "A Statistical snapshot of women in the Australian workforce," Australian Government: Department of Education, Skills, and Employment, March $8^{\text {th }} 2019$, https://www.employment.gov.au/newsroom/statistical-snapshot-women-australianworkforce (accessed on September 30th 2020).
} 
time average weekly earnings. ${ }^{37}$ The patriarchy concept accounts that with male domination in a relationship, it is more likely domestic violence occurs, because they employ many forms of control such as verbal abuse and financial control, to claim his authority in the relationship. ${ }^{38}$ With the pandemic still happening, affecting financial instability to some Australian households, creates a condition where men feel that women are a burden because of their financial dependence. Hence, domestic violence occurs. In reality, some women cannot help their family financially because the inequality that is happening in Australia, that does not give an equal opportunity and wage for women.

\section{Indonesia}

Domestic violence is sadly nothing new in Indonesia. According to the National Commission for Women, violence against women in the last 12 years have increased by $792 \%$ or eight times its initial amount. ${ }^{39}$ Ali Khasan, an assistant deputy of the Women and Children's Affairs Ministry's bureau of Protection of Women from Domestic Violence branch has stated that the levels of domestic violence in Indonesia is a marked concern. ${ }^{40}$ Based on UNDP data, Indonesia is ranked as a category 3 country on the Gender Development Index rankings. This means that Indonesia is considered 'average' in terms of the implementation of gender equality measures. ${ }^{41}$ This fact is very much in line with the National Commission for Women's noting of how domestic violence cases in Indonesia has increased by $71 \%$ or 9,637 cases in just the one-year span between 2018 to 2019 - by no means a small amount. ${ }^{42}$

The high levels of domestic violence in Indonesia worsened since the onset of the pandemic, a fact that has been confirmed with an interview with an NGO volunteer, Karmila Yusup who is part of the Pasundan Durbang Women Crisis Center (WCC). WCC was established in 2013 with the purpose of tacking gender inequality issues, such as but not limited to domestic violence against women. WCC also deals with rape and human trafficking, from direct legal emergency aid to subsequent recovery programs. Another thing WCC has done is also being actively involved in the making of the Sexual Violence Prevention act bill (RUU-PKS), which sadly has not been passed by the Indonesian house of representatives as of writing this paper. The problem with domestic violence is not a new issue endemic to only the time of the pandemic. Based on Karmila Yusup's statements however, the amount of domestic violence cases happening during the pandemic has almost doubled.

\footnotetext{
37 “Gender workplace statistics at a glance 2020," Australian Government, August 2020, https://www.wgea.gov.au/data/factsheets/gender-workplace-statistics-at-a-glance-

2020\#: :text=Workforce\%20Participation,part\%2Dtime\%20\%5B1\%5D.\&text=The\%20workforce\%20participation\%20rate* *,February\%202020)\%20\%5B4\%5D. (accessed on September 30 ${ }^{\text {th }} 2020$ ).

38 Steven R. Tracy, "Patriarchy and Domestic Violence: Challenging Common Misconceptions," JETS 50 No. 3 (2007): pg 583.

39 "Siaran Pers dan Lembar Fakta Komnas Perempuan: Catatan Tahunan Kekerasan terhadap Perempuan 2020", Komnas Perempuan, March 6th 2020, https://www.komnasperempuan.go.id/read-news-siaran-pers-dan-lembar-fakta-komnasperempuan-catatan-tahunan-kekerasan-terhadap-perempuan-2020 (accessed on September 25th 2020)

40 "Kasus Meningkat, Kemen PPPA Ajak Milenial Cegah KDRT", Kementrian Pemberdayaan Perempuan dan Perlindungan Anak Republik Indonesia, March 25th 2019, https://kemenpppa.go.id/index.php/page/read/29/2089/kasus-meningkat-kemenpppa-ajak-milenial-cegah-kdrt (accessed on September 25th 2020)

41 "Gender Development Index," Human Development Report 2019, page 312-315, http://hdr.undp.org/en/content/table-4gender-development-index (accessed on September 30th 2020)

42 "Kasus Meningkat, Kemen PPPA Ajak Milenial Cegah KDRT", Kementrian Pemberdayaan Perempuan dan Perlindungan Anak Republik Indonesia, March 25th 2019, https://kemenpppa.go.id/index.php/page/read/29/2089/kasusmeningkat-kemen-pppa-ajak-milenial-cegah-kdrt (accessed on September 25th 2020)
} 
Despite rising domestic violence cases according to recorded data, it is a known fact that many victims of domestic violence are still not counted as they refuse to file a report. This goes in line with the statement of one Vennetia R. Dannes, departmental deputy of Women's Rights in the WCC. She stated that during the pandemic, reports of domestic violence cases have actually decreased from 769 from 1 January - 28 February, to only 523 from 29 February - 10 June. This has raised concerns in the WCC as it indicates that many victims are not even able to attempt to better their situations at home. It may even in the long term generate a steadily much higher level of domestic violence cases. ${ }^{43}$

According to Karmila, there are a few factors that prevent a domestic violence victim from filing a report to the relevant authorities. Among these reasonings is the very fact that the victims themselves do not know how to file a formal report to authorities. Aside from a lack of understanding regarding bureaucratic matters related to filing a report, many victims also feel that instances of domestic violence are a stain on family honor and reputation, and thus choose to rather hide it instead of reporting it. Aside from that, there is still also the existing misled way of thinking in Indonesia that violence can help instill moral and holistic values in 'truant' children or women - two members of the household often seen as deserving less power in Indonesian culture. There is also the widespread factor of the victims not doing anything in order to protect themselves or the victim from being 'punished' harsher by the regular abuser.

Interestingly, domestic violence in Indonesia is not endemic to just the lower economic class. It occurs in every layer of society no matter their socioeconomic or economic background. In fact, academics and religious figures are also prone to doing such abominable acts. This is due to the fact that the economy is not the strongest factor in the presence of domestic violence, but rather the mentality of the household. Power relations in most Indonesian households dictate that men have the right to exert total control upon the women and children of the household. This place the men in positions of power socially speaking, often deluding them into thinking that they are justified to do whatever is 'good for the family' in their eyes. This has been done and normalized at the expense of the vulnerable women and children whose household patriarch are violent abusers.

Sadly, domestic violence between family members are not the only problem in Indonesia, but also violence against household assistants - in other words the maid or the help who often live-in at home with the family they work for. Domestic violence against these even more economically vulnerable members of society is also very much a widespread problem that prevails in Indonesia. Although the number one most reported type of domestic violence cases in Indonesia are still husband against wife, this aforementioned type of violence is also prevalent and even more often unreported. Another normalized form of domestic violence in Indonesia is one done against children. This type of violence has also increased markedly during the pandemic, often due to frustrations by the parents who are unable to serve as ample educators for their children who are still unable to go to school due to the lockdown. ${ }^{44}$

\footnotetext{
43 “Kemen PPPA Waspadai Adanya Kasus KDRT Tersembunyi Sejak WFH di Masa Pandemi”, Kementrian Pemberdayaan Perempuan dan Perlindungan Anak Republik Indonesia, June 12th 2020, https://kemenpppa.go.id/index.php/page/read/29/2725/kemen-pppa-waspadai-adanya-kasus-kdrt-tersembunyi-sejak-wfh-dimasa-pandemi (accessed on September 27th 2020)

44 “KDRT Mengintai Ditengah Pandemi”, Kementrian Pemberdayaan Perempuan dan Perlindungan Anak Republik Indonesia, May 31th 2020, https://www.kemenpppa.go.id/index.php/page/read/31/2707/kdrt-mengintai-di-tengah-pandemi (accessed on September 27th 2020)
} 
The problem of domestic violence that keep increasing in terms of incidence is not being offset by the initiatives conducted by various social organizations such as WCC. This is due to the fact that prior to the pandemic, the WCC used to engage in more interruptive measures such as home visits, direct consultation and even rehabilitation of victims in shelters. However, since the pandemic these kinds of steps have also become more difficult as social distancing measures would not allow the more interruptive measures to take place. In fact, the WCC shelter for women has been forced to be closed due to its inhabitants testing positive for Covid-19.

With this more challenging condition, the government has been accused of not doing enough to help rectify the issue. The policy that is still being pursued during the pandemic has still been one that prioritizes virus containment and physical health. There is little to no measures taken to alleviate the issue of domestic violence. Legally speaking, Indonesia has Regulation 23 of the year 2004 regarding the abolishment of domestic violence. This law only helps the victims of domestic violence handle their cases as the law codifies what constitutes as domestic violence. However, abysmal jurisprudence and cultural biases often result in the misinterpretation and even misuse of said law with many victims even becoming victims of the law itself turning against them and they end up having to pay concessions to their abusers.

The lack of education regarding gender equality for law enforcement agents and administrators has become the reason such a warp in the legal system has occurred. If left unchecked and ignored, domestic violence cases will continue to rise in Indonesia. However reported cases continue to occur as many victims are still completely unsure as to how the authorities would even be of any help to them. The government of Indonesia apparently still tries to fix this issue. To this end, direct observation of ongoing cases or rehabilitated victims would definitely be helpful in contextualizing and internalizing the seriousness of the situation in these administrators and law enforcement agents. The Indonesian legislation is also hoped to result in some form of substantial measure in legal reforms in order to stamp out this ongoing long-term problem.

\section{$\underline{\text { India }}$}

India is a country that is ranked low on the Gender Development Index rankings. Violence against women in India, especially in the form of rape, is a very commonly heard-of problem that plagues the country. High-profile gang rape cases where the victims are then murdered by the perpetrators continuously appear in international media coverage - a telltale sign of the prevalence of this type of violence. ${ }^{45}$ The problem has understandably attracted protesters within India itself as many in the population do not feel that government authorities have not done enough to placate the problem. ${ }^{46}$

Domestic violence is yet another manifestation of the abysmal gender equality situation in the country. Due to the financial difficulties faced by many families with female economic dependents, a by-product of the patriarchal norm of the man being the sole breadwinner, many women are facing

\footnotetext{
${ }^{45}$ The Quint, "India's Rape Crisis: 106 Rapes Per Day, 4 in 10 Victims Minors," TheQuint, April 16th2018, https://www.thequint.com/news/india/india-rape-data-106-rapes-per-day-4-in-10-victims-minors. (accessed on September 28th 2020)

${ }^{46}$ WION Web Team, "Protests in India after Late Night Cremation of Gang Rape Victim," WION , https://www.wionews.com/india-news/protests-in-india-after-late-night-cremation-of-gang-rape-victim-331576. (accessed on September 28th 2020)
} 
more instances of domestic violence. The frustration generated in many men's minds from not being able to generate money from work or enterprising as they would before the lockdown is then compounded by the patriarchal notion that places the woman as being another burden on the part of the working man's shoulders. This notion then fuels the financial frustrations plaguing many men to be taken out violently on their wives whom they view as being another reason for their woes. ${ }^{47}$

Aside from obvious toxic masculinity being a driving force for India's ghastly gender inequality, culture is in fact another problem. Many Indians still believe in the traditional Hindu caste system that ranks a person's standing in society for their entire lives. This has enabled many rapes against women of lower castes, especially the 'untouchable' dalit class of predetermined social pariahs, to occur and in large numbers. ${ }^{48}$

According to one Gunjeeta Singh, an Indian woman who also heads an NGO that specializes in highlighting endemic issues in the many states of India, domestic violence is akin to being part of the culture. This implies not only the prevalence but also the normalization domestic violence receives from the general population of the country. The onset of the COVID-19 Pandemic and the subsequent lockdown has indeed been occurring on a more regular basis compared to before the Pandemic. ${ }^{49}$ This problem however, is being actively recognized and tackled by the government using a slew of new methods.

One of the ways Indian women facing domestic violence is able to escape their conundrum is by calling one of the more than 50 helplines through the mobile application Whatsapp or direct call. ${ }^{50}$ These newly established communication lines would then help the woman live in another home, as they would be escorted by law enforcement for their safety to live in a designated temporary home that is usually hosted by one of many newly-established women's shelters. The opposite is also done to abusive men as they would sometimes be the ones relocated to live elsewhere in the case of the woman having children. According to Gunjeeta, the presence of these emergency channels has seen the relocation of thousands of women nationwide. The presence of these helplines is one that is initiated by the government, but is by and large also done altruistically by various social foundations and institutions of religion.

The presence of these helplines however still paints the state of India's gender inequality problem. Despite the presence of such initiatives, the fact of the matter is that violence against women in India in its many forms is still very much commonplace. The strongly patriarchal culture that dominates most Indians is compounded by various other disenfranchising factors which lead to the already vulnerable women to be prone to act as punching bags for problems that have transcended their own control - as it is clearly a social and cultural problem. As of writing this paper, another highprofile rape and murder of a teenage dalit girl has become a media fire. ${ }^{51}$ The public outcry against the

\footnotetext{
${ }^{47}$ Mahapatro, M., Gupta, R., \& Gupta, V,"The risk factor of domestic violence in India”, Indian journal of community medicine : official publication of Indian Association of Preventive \& Social Medicine, 37(3) (2012):pg 153-157.

${ }^{48}$ Harshita Rathore, "Rape, Caste, Double Standards, and India's Middle Class," - The Diplomat, February 20, 2020), https://thediplomat.com/2020/02/rape-caste-double-standards-and-indias-middle-class/. (accessed on September 28th 2020)

49 Ayushree Nandan, "Is Domestic Violence the next Pandemic in India?," Times of India Blog, May 21, 2020, https://timesofindia.indiatimes.com/blogs/voices/is-domestic-violence-the-next-pandemic-in-india/. (accessed on September 28th 2020)

${ }^{50}$ Geetika Sachdev, “Domestic Violence Sees No Lockdown; NCW's WhatsApp Helpline Is a Saviour for Women,” Yahoo! May 7, 2020, https://in.makers.yahoo.com/domestic-violence-sees-no-lockdown-nc-ws-whats-app-helpline-is-a-saviour-forwomen-044112701.html. (accessed on September 28th 2020)

51 WION Web Team, "Protests in India after Late Night Cremation of Gang Rape Victim," WION, October 1, 2020 , https://www.wionews.com/india-news/protests-in-india-after-late-night-cremation-of-gang-rape-victim331576\#: : :text=Protests\%20erupted\%20in\%20several\%20parts, the \%20consent $\% 20$ of $\% 20$ her $\% 20$ family.\&text=Angry $\% 20 \mathrm{p}$
} 
rape is then worsened by the Indian authorities' mishandling of the situation - a sign that the strongly misogynistic elements of Indian society have infiltrated even the authorities. However, the silver lining in this cloud is that the national public outcry at least indicates how there is in fact, a healthy amount of people in India willing to tackle this issue of violence against women.

\section{Conclusion}

The COVID 19 pandemic, is affecting the daily lives of many people around the world. Even though there has not been much research on domestic violence during the pandemic, there is already some data that shows an increase in the number of this issue. In a comparative study between the three countries that have different Gender Development Index categories, it was found that during the pandemic there was an increase in the number of domestic violence that occurred in households. Physical distancing and quarantine policies that are enforced in several countries, have made almost all people carry out their activities from home, changing everyone's daily life. This pandemic has sparked domestic violence, some of the factors being the changing forms of activities that force people to stay at home. For example, in Indonesia there is a lot of domestic violence practiced by parents because they feel that their children are difficult to teach because of a change in the form of learning from in class to at home online. Other triggers are financial problems and job security uncertainty caused by the pandemic. In addition, gender inequality, patriarchal culture, and toxic masculinity that still exist in these three countries are the reasons why the number of domestic violence has increased. Because, women are considered as a burden that must be financed, at the same time the conditions are uncertain, and the opportunities that women have are also smaller. Therefore, many men channel their emotions through violence to their families.

During this pandemic, victims of domestic violence were hampered by the policy of physical distancing. Victims of domestic violence who want to report to related parties will find it difficult to contact them because they are under the same roof with the perpetrators. In addition, even if they report and try to leave their homes, victims of domestic violence who are looking for a place in the shelter provided will be exposed to COVID 19, so they feel better at home even with the people who abuse them. Another factor that hinders victims of domestic violence is financial dependence, which makes women reluctant to leave their homes, because if they leave, they will not be able to survive. A number of efforts have been made by the governments of these three countries, such as funding, improving the quality of public services, and shelters. However, the authors feel that there needs to be more attention to the issue of domestic violence, because if it is not responded to properly, it can spread to other issues in a country, such as the increase in the prevalence of COVID 19, human rights violations, and disturbed mental health of victims. Some of the ways that the three countries can do is to expand the scope of the issues that are being dealt with, because this pandemic does not only affect health and the economy. In addition, the government can make or improve facilities such as application or telephone numbers that can be used by the community to report domestic violence, and integrate with local authorized institutions such as police, or local NGOs for help. 


\section{Bibliography}

2019. Australian Bureau of Statistics. 9 July. Accessed September 28, 2020. https://www.abs.gov.au/statistics/people/crime-and-justice/recorded-crime-victimsaustralia/latest-release\#victims-of-family-and-domestic-violence-related-offences .

2017. Australian Bureau of Statistics. 2018 November. Accessed September 29, 2020. https://www.abs.gov.au/statistics/people/crime-and-justice/personal-safetyaustralia/latest-release.

2020. Australian Government. August. Accessed September 30, 2020. https://www.wgea.gov.au/data/fact-sheets/gender-workplace-statistics-at-a-glance2020\#: :text=Workforce\%20Participation,part\%2Dtime\%20\%5B1\%5D.\&text=The\% 20workforce\%20participation\%20rate**,February\%202020)\%20\%5B4\%5D.

n.d. Australian Government Services Australia. Accessed September 30, 2020. https://www.servicesaustralia.gov.au/individuals/services/centrelink/jobseekerpayment/who-can-get-it .

2019. Australian Government: Department of Education, Skills, and EMployment. 8 March. Accessed September 30, 2020. https://www.employment.gov.au/newsroom/statisticalsnapshot-women-australian-workforce.

Carrington, Kerry. 2003. Parliament of Australia. 7 August. Accessed September 28, 2020. https://www.aph.gov.au/about_parliament/parliamentary_departments/parliamentary_1 ibrary/publications_archive/archive/domviolence .

Creswell, John C. 2009. Research Design: Qualitative, Quantitative, and Mixed Method Approaches . California: SAGE Publications.

Emma Dawson, Tanja Kovac, and Abigail Lewis. 2020. "Measure for Measure: Gender Equality in Australia." PerCapita 7.

Galloway, Anthony. 2020. The Sydney Morning Herald. 13 July. Accessed September 27, 2020. https://www.smh.com.au/politics/federal/domestic-violence-on-the-rise-duringpandemic-20200712-p55b8q.html.

Government, Australian. 2020. Statistical Bulletin. Statistical Bulletin, Australia: Australian Institue of Criminology.

2019. Kementrian Pemberdayaan Perempuan dan Perlindungan Anak Republik Indonesia. 25 March. 
https://kemenpppa.go.id/index.php/page/read/29/2089/kasus-meningkat-kemen-pppaajak-milenial-cegah-kdrt .

2020. Kementrian Pemberdayaan Perempuan dan Perlindungan Anak Republik Indonesia. 12 $\begin{array}{llll}\text { June. } & \text { Accessed } & \text { 20 } & \end{array}$ https://kemenpppa.go.id/index.php/page/read/29/2725/kemen-pppa-waspadai-adanyakasus-kdrt-tersembunyi-sejak-wfh-di-masa-pandemi.

2020. Kementrian Pemberdayaan Perempuan dan Perlindungan Anak Republik Indonesia. 31 $\begin{array}{llll}\text { May. } & \text { Accessed } & 2020 .\end{array}$ https://www.kemenpppa.go.id/index.php/page/read/31/2707/kdrt-mengintai-ditengah-pandemi .

Kleyman, Kelly L. Hazel and Kerry S. 2019. "Gender and sex inequalities: Implications and resistance." Journal of Prevention and Intervention in the Community .

2020. Komnas Perempuan. 6 March. Accessed September 25, 2020. https://www.komnasperempuan.go.id/read-news-siaran-pers-dan-lembar-faktakomnas-perempuan-catatan-tahunan-kekerasan-terhadap-perempuan-2020.

L.Davis, Richard. 2008. Domestic Violence: Intervention, Prevention, Policies, and Solutions. Boca Raton: Taylor \& Francis Group.

Mahapatro, M., Gupta, R., \& Gupta, V. 2012. "The risk factor of domestic violence in India." Indian journal of community medicine : official publication of Indian Association of Preventive \& Social Medicine, 37(3) 153-157.

Nation, United. 2020. "Policy Brief: The Impact of COVID-19 on Women." (United Nation) 14.

Pateman, Carole. 2016. "Sexual Contract." The Wiley Blackwell Encyclopedia of Gender and Sexuality Studies 1-3.

Quint, The. 2018. The Quint. 16 April. Accessed September 28, 2020. https://www.thequint.com/news/india/india-rape-data-106-rapes-per-day-4-in-10victims-minors.

Rathore, Harshita. 2020. The Diplomat. 20 February. Accessed September 28, 2020. https://thediplomat.com/2020/02/rape-caste-double-standards-and-indias-middleclass/.

Ross, Lee E. 2018. Domestic Violence and Criminal Justice. New York: Routledge.

Sachdev, Geetika. 2020. Yahoo! 7 May. Accessed September 28, 2020. https://in.makers.yahoo.com/domestic-violence-sees-no-lockdown-nc-ws-whats-apphelpline-is-a-saviour-for-women-044112701.html. 
Sarwono, Billy K. 2012. " Gender Bias in a Patriarchal Society." Wacana 14,no.1 37-60.

2020. Times of India Blog. 21 May. Accessed Septeber 28, 2020. https://timesofindia.indiatimes.com/blogs/voices/is-domestic-violence-the-nextpandemic-in-india/.

Tracy, Steven R. 2007. "Patriarchy and Domestic Violence: Challenging Common Misconceptions." JETS 50 No. 3583.

2020. UN Women. Accessed September 21, 2020. https://www.unwomen.org/en/digitallibrary/publications/2020/06/brief-domestic-violence-in-the-world-of-work .

2020. UN Women. 27 May. Accessed September 21, 2020. https://www.unwomen.org/en/news/stories/2020/5/press-release-the-shadowpandemic-of-violence-against-women-during-covid-19.

UNFPA. 2005. United Nations Population Fund. Accessed September 24, 2020. https://www.unfpa.org/resources/frequently-asked-questions-about-gender-equality .

2020. United Nation. Accessed September 24, 2020. https://www.un.org/sustainabledevelopment/wp-content/uploads/2016/08/5_Why-ItMatters-2020.pdf .

2019. United Nation Development Programme Human Development Report. Accessed September 30, 2020. http://hdr.undp.org/en/content/table-4-gender-developmentindex.

Wahlquist, Calla. 2020. The Guardian. 1 May. Accessed September 27, 2020. https://www.theguardian.com/world/2020/may/02/australias-coronavirus-lockdownthe-first-50-days.

2020. WION . Accessed September 29, 2020. https://www.wionews.com/india-news/protestsin-india-after-late-night-cremation-of-gang-rape-victim331576\#: :text=Protests\%20erupted $\% 20$ in $\% 20$ several\%20parts,the $\% 20$ consent $\% 20 \mathrm{o}$ f $\% 20$ her $\% 20$ family.\&text=Angry $\% 20$ protesters $\% 2 \mathrm{C} \% 20$ many $\% 20$ wearing $\% 20$ masks ,Uttar\%20Pra.

n.d. WION. Accessed September 28, 2020. https://www.wionews.com/india-news/protests-inindia-after-late-night-cremation-of-gang-rape-victim-331576. .

2020. World Health Organization. 21 January. Accessed September 21, 2020. https://www.who.int/docs/default-source/coronaviruse/situation-reports/20200121sitrep-1-2019-ncov.pdf . 
124 Jessica Ruth Andina, Marvel Tanara, Dzaky Putra Wirahman | The Correlation between the Covid-19

Pandemic and Domestic Abuse Against Women: A Comparative Study Between Australia, Indonesia, and India

2020. World Health Organization. 11 March. Accessed September 21, 2020. https://www.who.int/dg/speeches/detail/who-director-general-s-opening-remarks-atthe-media-briefing-on-covid-19---11-march-2020 